\title{
ASSESSMENT OF DOSE INTAKE OF TOXIC ELEMENTS IN GROUNDWATER SAMPLES FROM ABUJA, NORTH CENTRAL NIGERIA
}

\author{
OMEJE MAXWELL ${ }^{1}$, JOEL EMMANUEL SUNDAY ${ }^{1}$, ADEWOYIN OLUSEGUN OLADOTUN ${ }^{1}$, \\ AKINWUMI SAYO AKINLOYE ${ }^{1}$, PRAISEGOD CHIDOZIE EMENIKE ${ }^{2}$, \\ IMOKHAI THEOPHILUS TENEBE I ${ }^{2}$, OLATOKUNBO OFUYATAN ${ }^{2}$, \\ OKOLIE TOBIAS SOCIIS ${ }^{3}$, HUSIN WAGIRA ${ }^{4}$ \& HASSINA MOURI $^{5}$ \\ ${ }^{1}$ Department of Physics, Covenant University, Nigeria \\ ${ }^{2}$ Department of Civil Engineering, Covenant University, Nigeria \\ ${ }^{3}$ Department of Mechanical Engineering, Covenant University, Nigeria \\ ${ }^{4}$ Department of Physics, Universiti Teknologi Malaysia \\ ${ }^{5}$ Department of Geology, University of Johannesburg, South Africa
}

\begin{abstract}
This study measured the concentrations of toxic carcinogenic and non-carcinogenic elements present in groundwater using Inductively Coupled-Plasma Mass Spectrometry (ICP-MS). The concentration values obtained were used to calculate the life average daily dose (LADD) exposure of the people whom rely on groundwater for consumption in Abuja, Nigeria. The highest LADD for the carcinogenic toxic element chromium (Cr) was $2.7 \times 10^{-5} \mu \mathrm{g} \mathrm{kg}^{-1}$ day ${ }^{-1}$, whereas it was $3.3 \times 10^{-4} \mu \mathrm{g}$ $\mathrm{kg}^{-1}$ day $^{-1}$ for the non-carcinogenic toxic element lead (Pb), identified in water samples collected by the Water Board. These LADD magnitudes of $10^{-5}$ and $10^{-4}$ for both carcinogenic and noncarcinogenic toxic elements in groundwater are far below the International Reference Dose according to the United States Environmental Protection Agency (USEPA) in 2008, which has a value of $10^{-1}$. The low magnitudes found in water samples may not pose significant health risks to the local population. The relevant authorities should, therefore, continue to monitor the impact of human activities on metal pollution in this area and take effective measures to control contamination of the public water supply.
\end{abstract}

Keywords: Africa, chromium, contamination, dose intake, groundwater, lead, Nigeria, radionuclides, toxicity risk.

\section{INTRODUCTION}

Undoubtedly, high exposure to heavy metals in water has negative effects on human health, such as cancers and damage of the nervous system [1], [2]. Excess cadmium (Cd) can cause kidney stones, while excess lead $(\mathrm{Pb})$ can affect brain activity in children [2]. Once the heavy metals such as $\mathrm{Cd}$ and $\mathrm{Pb}$ are dispersed in water, soil and air, they could be accumulated by the crops [3], [4] if groundwater is used for irrigation. Toxicity to the human kidney by chronic ingestion of uranium (U) through drinking water in the range of 0.004 to $9 \mu \mathrm{g} \mathrm{L}^{-1}$ per body weight per day may produce interference with kidney functions [4]. In more recent studies on humans [5], nephrotoxic effects of $U$ in drinking water were found even for low concentrations, without a clear threshold. The activity concentration of radium $(\mathrm{Ra})$ in groundwater depends on the activity concentration of $\mathrm{Ra}$ in the bedrock and on mechanisms such as precipitation-dissolution, complexation, and adsorption-desorption that affect the transport of $\mathrm{Ra}$ in water. These processes are related to the chemical composition of groundwater [6]. Heavy metals are very toxic, bio-accumulative, and resistant to biochemical degradation: they can pose a potential threat to human health [8]. Heavy metals in urban soils can be readily transferred to humans by ingestion, inhalation, or dermal absorption; accumulate in fatty tissues, and subsequently affect the nervous system, endocrine system, immune system, hematopoietic function, normal cellular 
metabolism, etc. The International Commission on Radiological Protection (ICRP) [7] has estimated that gastrointestinal absorption of $\mathrm{R}$ from drinking water and food accounts for $15-21 \%$ of ingested $\mathrm{R}$.

Based on the EU directive that includes $\mathrm{U}$ and $\mathrm{R}$ isotopes, since thorium (Th) does not or hardly oxidizes in groundwater. This study is aimed at providing the potential radiological risks and chemical toxicity effects of exposure to the inhabitants relying on groundwater within and around Abuja. The geographical coordinates of the study area lie within the latitude (lat.) of $8^{\circ} 56^{\prime} 45.6^{\prime \prime} \mathrm{N}$ and longitude (long.) of $7^{\circ} 13^{\prime} 26.2^{\prime \prime} \mathrm{E}$ for the Gosa area; whereas Lugbe lies within the lat. of $8^{\circ} 59^{\prime} 2.3^{\prime \prime} \mathrm{N}$ and the long. of $7^{\circ} 23^{\prime} 7.8^{\prime \prime} \mathrm{E}$, respectively. Similarly, this study assesses the life average daily dose (LADD) of some toxic elements in the groundwater in Abuja. There is no available information on the life time average daily dose received by inhabitants that rely on groundwater-based drinking. The results of this study provided data on the toxicity risk exposure to inhabitants of Abuja.

\section{GEOLOGY OF THE STUDY AREA}

The Abuja area is located within the crystalline basement of Nigeria; with mainly migmatite, leucocratic granite, quartzmonite and granodiorite. The detailed geology and hydrogeology of the study area was reported elsewhere [9]. The drilling point coordinates of the Gosa area lie within the coordinate of lat.: $8^{\circ} 56^{\prime} 45.6^{\prime \prime} \mathrm{N}$ and long.: $7^{\circ} 13^{\prime} 26.2^{\prime \prime} \mathrm{E}$; whereas Lugbe lies within lat.: $8^{\circ} 59^{\prime} 2.3^{\prime \prime} \mathrm{N}$ and long.: $7^{\circ} 23^{\prime} 7.8^{\prime \prime}$ E. The boreholes drilled for this study, with lithologic units, are presented in Figs 1, 2, and 3, respectively.

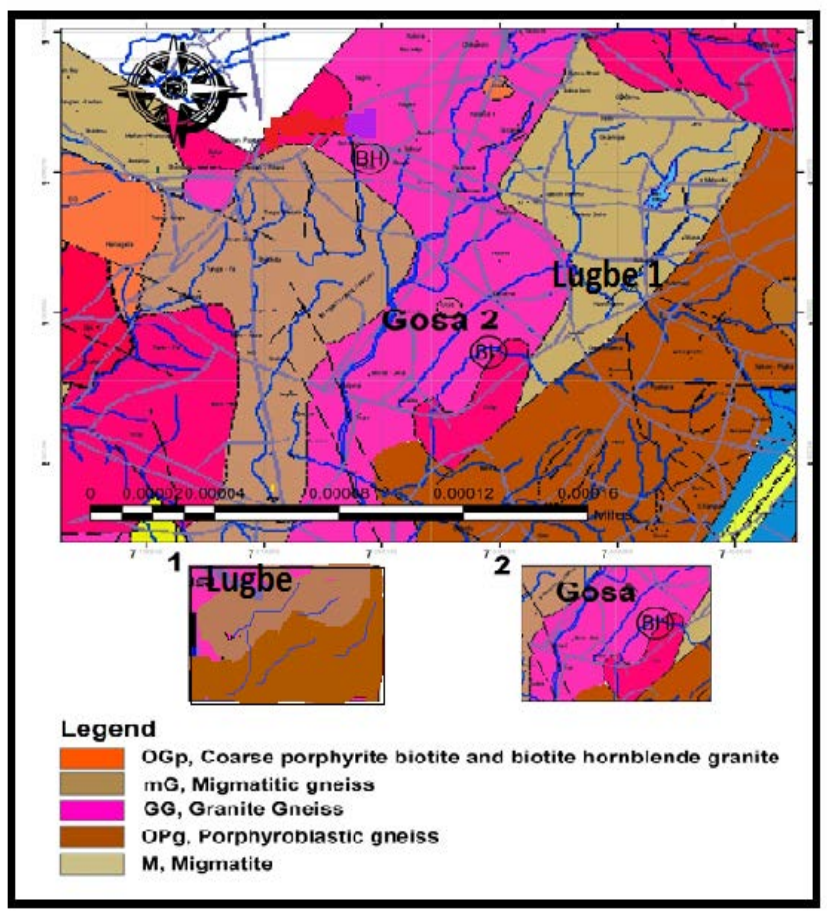

Figure 1: Geological map of the study area. 


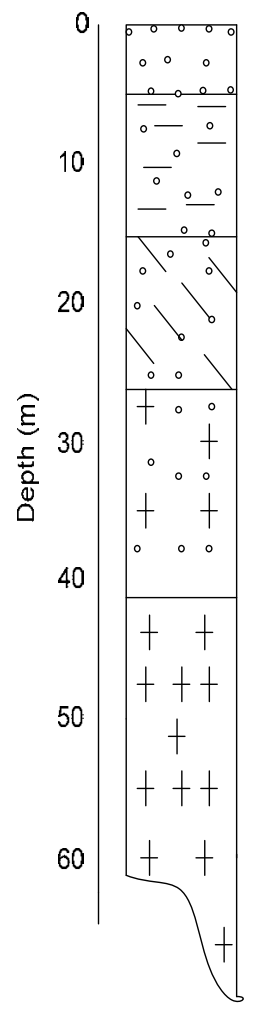

LEGEND

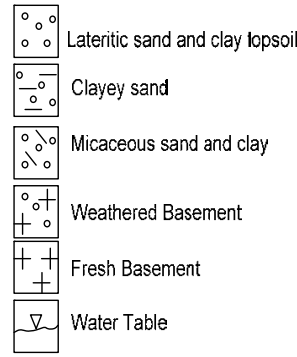

Figure 2: Lithologic log of representative borehole drilled around the Gosa area, to $50 \mathrm{~m}$ (lat.: $8^{\circ} 56^{\prime} 45.6^{\prime \prime}$ and long.: $7^{\circ} 13$ ' 26.2" E).

\section{MATERIALS AND METHODS}

\subsection{Sampling and sample preparation}

We collected six different water samples that could be used for consumption and domestic purposes in some parts of Abuja. The $\mathrm{pH}$ was measured on the spot, using a $\mathrm{pH}$ meter (model no. CONSORT C933). At the borehole points, water samples were collected in clean plastic bottles that had been washed several times with $20 \%$ nitric acid $\left(\mathrm{HNO}_{3}\right)$ and distilled water, for sterilization purposes. All the collected water samples were passed through filters and then $0.5 \mathrm{~mL}$ of $\mathrm{HNO}_{3}$ was added to hold the water constituents until reaching the laboratory for analysis. For the Inductively Coupled-Plasma Mass Spectrometry (ICP-MS) analysis, all the water samples collected were kept in a refrigerator at about $4-6{ }^{\circ} \mathrm{C}$, in order to measure their heavy metal concentrations next [10].

\subsection{Chemical analysis for heavy metals}

The acidified water samples were analysed for heavy metals (As, $\mathrm{Cd}, \mathrm{Cr}, \mathrm{K}, \mathrm{Mg}, \mathrm{Ni}, \mathrm{Pb}$ and $\mathrm{Zn}$ ) by using ICP-MS under standard operating conditions. In view of data quality 


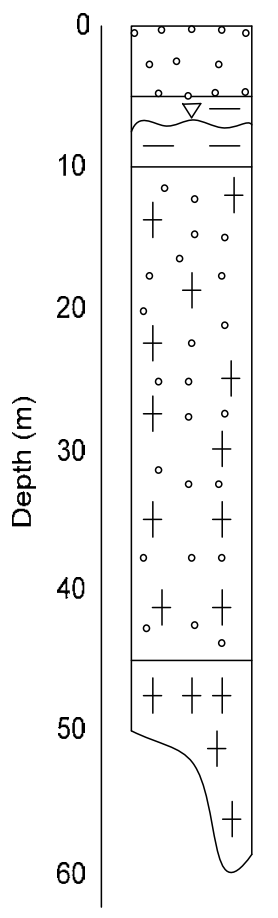

\section{LEGEND}

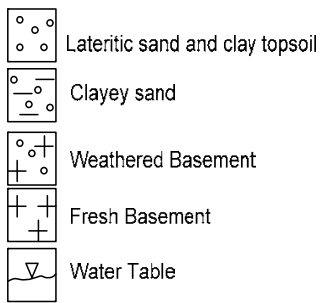

Figure 3: Lithologic log of representative boreholes drilled around the Lugbe area, to 40 $\mathrm{m}$ (lat.: $8^{\circ} 59^{\prime} 2.3^{\prime \prime} \mathrm{N}$ and long.: $7^{\circ} 23^{\prime} 7.8^{\prime \prime} \mathrm{E}$ ).

assurance, each sample was analysed in triplicate and after every 10 samples there were two standards, one blank and another of $2.5 \mu \mathrm{g} / \mathrm{L}$ of the respective metal, which were analysed on atomic absorption. Reproducibility was found to be at the $95 \%$ confidence level $(95 \% \mathrm{CI})$. Therefore, the average value of each water sample was used for further interpretation. Standard solutions of all eight elements were prepared by dilution of 1000 $\mathrm{mg} / \mathrm{L}$ of the certified standard solutions from the manufacturer for corresponding metal ions, with double distilled water. All the acids and reagents used were of analytical grade. The minimum detection limit of $0.22 \mathrm{BqL}^{-1}$ counting for 4 hours, and $0.09 \mathrm{BqL}^{-1}$ counting for 20 hours, which we adopted in this study according to previously published literature [10].

\section{RESULTS AND DISCUSSIONS}

4.1 The toxic element concentrations of water samples from the study area

Analysis of heavy metals from the water samples indicated there was variation in concentrations for $\mathrm{As}, \mathrm{Cr}, \mathrm{Cd}, \mathrm{Pb}, \mathrm{Ni}, \mathrm{Zn}, \mathrm{Mg}$ and $\mathrm{K}$ (Table 1). The concentrations were noted to vary respectively, from 0.0002 to $0.002 \mathrm{mg} / \mathrm{L}, 0.0003$ to $0.01 \mathrm{mg} / \mathrm{L}, 0.00006$ to $0.0003 \mathrm{mg} / \mathrm{L}, 0.0002$ to $0.014 \mathrm{mg} / \mathrm{L}, 0.001$ to $0.021 \mathrm{mg} / \mathrm{L}, 0.02$ to $0.277 \mathrm{mg} / \mathrm{L}, 0.037$ to $2.11 \mathrm{mg} / \mathrm{L}$, and 0.0006 to $1.41 \mathrm{mg} / \mathrm{L}$. It can be noted that samples collected from SabonLugbe, Kuje and the Water Board were distinctly higher than other samples for $\mathrm{As}, \mathrm{Pb}, \mathrm{Ni}$, 
$\mathrm{Zn}, \mathrm{Mg}$ and $\mathrm{K}$, respectively. This could be from the tectonic occurrence that stirred the ultrabasic and mafic igneous intrusion. Comparing the present study with other work reported elsewhere (Table 1); the $\mathrm{As}, \mathrm{Pb}, \mathrm{Ni}$ and $\mathrm{Zn}$ concentrations in the waters were noted to be higher in the Sabon-Lugbe borehole sample than others samples. This higher level could be attributed to basaltic dyke intrusion. The higher concentration of $\mathrm{Cr}$ and $\mathrm{Cd}$ reported at the Giri borehole may be due to shallow sources infiltrating the borehole. At the same time, all the measured samples are within the normal range of permissible limits, when compared [12], [13], [16].

4.2 Chemical toxicity risk of carcinogenic and non-carcinogenic elements in groundwater from the study area.

The World Health Organization (WHO) proposes a very similar reference value, called the Tolerable Daily Intake (TDI), as an estimate of the amount of a substance in food or drinking-water, also expressed on a body weight basis that can be ingested daily over a lifetime, without any appreciable health risk [18]. The TDI values take into account both systemic and carcinogenic effects, but the risk index is calculated as systemic. The exposure assessment of this work only considers the ingestion of drinking water containing pollutants through the oral route, as the unique pathway. The oral dose for each contaminant present in water was calculated by eqn $\mathrm{Di}$ :

$$
D_{i}=\frac{C_{W} \times E F \times E D \times I R_{W}}{B W \times A T \times 365_{\text {days } / \text { year }}}
$$

Table 1: Concentrations of heavy metals in the water samples from the study area, compared with other studies elsewhere [12], [19].

\begin{tabular}{|c|c|c|c|c|c|c|c|c|}
\hline \multirow{2}{*}{$\begin{array}{l}\text { Sample } \\
\text { location }\end{array}$} & \multicolumn{3}{|c|}{$\begin{array}{l}\text { Carcinogenic toxic elements } \\
\left(\mathrm{mg} \mathrm{L}^{-1}\right)\end{array}$} & \multicolumn{5}{|c|}{ Non-carcinogenic toxic elements $\left(\mathrm{mg} \mathrm{L}^{-1}\right)$} \\
\hline & As & $\mathrm{Cr}$ & $\mathrm{Cd}$ & $\mathrm{Pb}$ & $\mathrm{Ni}$ & $\mathrm{Zn}$ & $\mathrm{Mg}$ & K \\
\hline $\begin{array}{l}\text { Dawaki } \\
\text { borehole }\end{array}$ & 0.002 & 0.004 & 0.0001 & 0.005 & 0.003 & 0.02 & Nil & Nil \\
\hline $\begin{array}{l}\text { Kuje } \\
\text { borehole }\end{array}$ & 0.0002 & 0.002 & 0.00002 & 0.0002 & 0.002 & 0.04 & 2.11 & 1.41 \\
\hline $\begin{array}{l}\text { Giri } \\
\text { borehole }\end{array}$ & 0.0006 & 0.0003 & 0.0003 & 0.003 & 0.001 & 0.032 & 1.334 & 1.339 \\
\hline $\begin{array}{l}\text { Sabon- } \\
\text { Lugbe }\end{array}$ & 0.002 & 0.004 & 0.0001 & 0.014 & 0.021 & 0.277 & 0.037 & 0.0006 \\
\hline Water board & 0.001 & 0.01 & 0.0002 & 0.012 & 0.008 & 0.04 & Nil & Nil \\
\hline $\begin{array}{l}\text { Hand-dug } \\
\text { well }\end{array}$ & 0.003 & 0.001 & 0.00006 & 0.002 & 0.005 & 0.03 & Nil & Nil \\
\hline $\begin{array}{l}\text { Pereira- } \\
\text { Barbosa et } \\
\text { al. [12] }\end{array}$ & 0.05 & 0.1 & 0.005 & 0.010 & 0.07 & 0.07 & 0.05 & - \\
\hline $\begin{array}{l}\text { Gbadebo } \\
{[20]}\end{array}$ & - & - & - & - & - & - & - & 8.0 \\
\hline
\end{tabular}


Table 2: The dose intake (Di) in $\mu \mathrm{g} \mathrm{kg}^{-1}$ day $^{-1}$ for carcinogenic elements.

\begin{tabular}{|c|c|c|c|}
\hline Sample locations & \multicolumn{3}{|c|}{${\mathrm{Di} \mu \mathrm{kg}^{-1} \text { day }^{-1} \text { for carcinogenic elements versus the US EPA }}$ standard values } \\
\hline & $(\mathrm{As})$ & $(\mathrm{Cr})$ & $(\mathrm{Cd})$ \\
\hline Dawaki borehole & $5.4794 \times 10^{-8}$ & $1.0959 \times 10^{-7}$ & $2.7397 \times 10^{-9}$ \\
\hline Kuje borehole & $5.4794 \times 10^{-9}$ & $5.4794 \times 10^{-8}$ & $5.4794 \times 10^{-10}$ \\
\hline Giri borehole & $1.6438 \times 10^{-8}$ & $8.2191 \times 10^{-9}$ & $8.2191 \times 10^{-9}$ \\
\hline Sabon-Lugbe borehole & $5.4794 \times 10^{-8}$ & $1.0959 \times 10^{-7}$ & $2.7397 \times 10^{-9}$ \\
\hline Water Board & $2.7397 \times 10^{-8}$ & $2.7397 \times 10^{-7}$ & $5.4794 \times 10^{-9}$ \\
\hline Hand-dug well & $8.2191 \times 10^{-8}$ & $2.7397 \times 10^{-8}$ & $1.6438 \times 10^{-9}$ \\
\hline US EPA [21] & $6 \times 10^{-1}$ & $6 \times 10^{-1}$ & $6 \times 10^{-1}$ \\
\hline
\end{tabular}

Di represents the dose intake of contaminant by water ingestion $\left(\mu \mathrm{g} \mathrm{Kg}^{-1}\right.$ day $\left.^{-1}\right), \mathrm{C}_{\mathrm{w}}$ is the annual average concentration of the contaminant in water $(\mu \mathrm{gL}-1), \mathrm{EF}$ is the exposure frequency to the contaminated media (day year ${ }^{-1}$ ), ED is the exposure duration (year), $\mathrm{IR}_{\mathrm{w}}$ is the rate of water intake $\left(\mathrm{L} \mathrm{day}^{-1}\right), \mathrm{BW}$ is the body weight of the receptor $(\mathrm{Kg})$, and AT is the average lifetime of a person (year).The values obtained were compared with the reference dose (RFD) of $6 \times 10^{-1} \mu \mathrm{g} \mathrm{kg}^{-1}$ day $^{-1}$ [18], used as a standard criterion for toxic metal intake.

In Table 2, the Di for As ranged from $1.7 \times 10^{-9}$ to $8.2 \times 10^{-8} \mu \mathrm{g} \mathrm{kg}^{-1} \mathrm{day}^{-1}$, with the highest value noted in the hand-dug well, with a value of $8.2 \times 10^{-8} \mu \mathrm{g} \mathrm{kg}^{-1} \mathrm{day}^{-1}$. The lowest value was observed in the Giri borehole water sample. Comparing this highest value noted at the hand-dug well water sample with the reference dose (RfD) of $\mu \mathrm{g} \mathrm{kg}^{-1}$ per day is the maximum daily dose of a metal from a specific exposure pathway, for both adults and children [18] with a value of $6 \times 10^{-1} \mu \mathrm{g} \mathrm{kg}^{-1} \mathrm{day}^{-1}$, the present study is far lower. The Di for $\mathrm{Cr}$ ranges from $8.2 \times 10^{-9}$ to $2.7 \times 10^{-7} \mathrm{\mu g} \mathrm{kg}^{-1}$ day $^{-1}$ with the highest value noted in the Water Board sample well, a value of $2.7 \times 10^{-7} \mathrm{~g} \mathrm{~kg} \mathrm{k}^{-1} \mathrm{day}^{-1}$, and the lowest value reported in the Giri borehole water sample. The highest value is lower that the international standard, when compared with USEPA [18], with a value of $6 \times 10^{-1} \mu \mathrm{g} \mathrm{kg}^{-1} \mathrm{day}^{-1}$. For Cd, The Di ranges from $5.5 \times 10^{-10}$ to $8.2 \times 10^{-9} \mu \mathrm{g} \mathrm{kg}^{-1} \mathrm{day}^{-1}$, with the highest value noted in the Giri sample with a value of $8.2 \times 10^{-9} \mu \mathrm{g} \mathrm{kg}^{-1} \mathrm{day}^{-1}$ and lowest value reported in the Kuje borehole water sample. The highest value is lower than that the international standard, when compared with the USEPA [18], with a value of $6 \times 10^{-1} \mu \mathrm{g} \mathrm{kg}^{-1} \mathrm{day}^{-1}$.

For the non-carcinogenic elements presented in Table 3, the $\mathrm{Di}$ for $\mathrm{Pb}$ ranges from $5.5 \times 10^{-9}$ to $3.3 \times 10^{-4} \mu \mathrm{g} \mathrm{kg}^{-1} \mathrm{day}^{-1}$, with the highest value observed in the Water Board sample with a value of $3.3 \times 10^{-4} \mu \mathrm{g} \mathrm{kg}{ }^{-1} \mathrm{day}^{-1}$, and the lowest value reported for the Kuje borehole water sample. Comparing the highest value of $\mathrm{Pb}$ obtained in the study with the International Standard with a value of $6 \times 10^{-1} \mu \mathrm{g} \mathrm{kg}^{-1} \mathrm{day}^{-1}$, the present study $\mathrm{Di}$ with a value of $3.3 \times 10^{-4} \mu \mathrm{g} \mathrm{kg}^{-1} \mathrm{day}^{-1}$ is lower. For $\mathrm{Ni}$, the Di ranges from $2.7 \times 10^{-8}$ to $5.8 \times 10^{-7} \mu \mathrm{g} \mathrm{kg}^{-1}$ day $^{-1}$, with the highest value observed in the Sabon-Lugbe borehole water sample with a value of $5.8 \times 10^{-7} \mathrm{Mg} \mathrm{kg}^{-1}$ day $^{-1}$ and the lowest value reported at the Kuje borehole. Comparing the highest value of Ni obtained in the Sabon-Lugbe with the International Standard value of $6 \times 10^{-1} \mu \mathrm{g} \mathrm{kg}^{-1}$ day $^{-1}$, the present study Di with a value $5.8 \times 10^{-7} \mu \mathrm{g} \mathrm{kg}^{-1} \mathrm{day}^{-1}$ was found to be lower. The Di for $\mathrm{Zn}$ ranges from $5.5 \times 10^{-7}$ to $7.6 \times 10^{-6} \mu \mathrm{g} \mathrm{kg}^{-1} \mathrm{day}^{-1}$; with the highest value observed in the SabonLugbe borehole water sample, with a value of $7.6 \times 10^{-6} \mu \mathrm{g} \mathrm{kg}^{-1} \mathrm{day}^{-1}$ and the lowest value reported in the Dawaki borehole water sample. 
Table 3: Dose intake (Di in $\mu \mathrm{g} \mathrm{kg}^{-1}$ day $^{-1}$ ) for non-carcinogenic elements.

\begin{tabular}{|c|c|c|c|c|}
\hline Sample Locations & \multicolumn{3}{|c|}{$\mathrm{Di} \mu \mathrm{gg}^{-1} \mathrm{day}^{-1}$ for Non-Carcinogenic Elements } \\
\hline & $\mathrm{Di}(\mathrm{Pb})$ & $\mathrm{Di}(\mathrm{Ni})$ & $\mathrm{Di}(\mathrm{Zn})$ & $\mathrm{Di}(\mathrm{Mg})$ \\
\hline Dawaki borehole & $1.3699 \times 10^{-7}$ & $8.2191 \times 10^{-8}$ & $5.4794 \times 10^{-7}$ & $\mathrm{Nil}$ \\
\hline Kuje borehole & $5.4794 \times 10^{-9}$ & $5.4794 \times 10^{-8}$ & $1.0959 \times 10^{-6}$ & $\begin{array}{c}5.7808 \times \\
10^{-5}\end{array}$ \\
\hline Giri borehole & $8.2191 \times 10^{-8}$ & $2.7397 \times 10^{-8}$ & $8.7670 \times 10^{-7}$ & $\begin{array}{c}3.6548 \times \\
10^{-5}\end{array}$ \\
\hline $\begin{array}{c}\text { Sabon-Lugbe } \\
\text { borehole }\end{array}$ & $3.8356 \times 10^{-7}$ & $5.7534 \times 10^{-7}$ & $7.5889 \times 10^{-6}$ & $\begin{array}{c}1.0137 \times \\
10^{-7}\end{array}$ \\
\hline Water Board & $3.2876 \times 10^{-4}$ & $2.1918 \times 10^{-7}$ & $1.0959 \times 10^{-6}$ & $\mathrm{Nil}$ \\
\hline Hand-dug well & $5.4794 \times 10^{-8}$ & $1.3699 \times 10^{-7}$ & $8.2191 \times 10^{-7}$ & $\mathrm{Nil}$ \\
\hline$[14][18]$ & $6 \times 10^{-1}$ & $6 \times 10^{-1}$ & $6 \times 10^{-1}$ & $6 \times 10^{-1}$ \\
\hline
\end{tabular}

The Di for Mg ranges from $1.0 \times 10^{-7}$ to $5.8 \times 10^{-5} \mu \mathrm{g} \mathrm{kg}^{-1}$ day ${ }^{-1}$, with the highest value observed in the Kuje borehole water sample, with a value of $5.8 \times 10^{-5} \mu^{\mathrm{g} \mathrm{kg}} \mathrm{kg}^{-1} \mathrm{day}^{-1}$ and the lowest value reported in the Sabon-Lugbe borehole water sample. Comparing the highest value noted at the Kuje borehole water sample with the international standard, USEPA [18] with a value of $6 \times 10^{-1} \mu \mathrm{g} \mathrm{kg}^{-1} \mathrm{day}^{-1}$, the present study for $\mathrm{Mg}$ is lower, with a value of $\sim 5.8 \times 10^{-5} \mu \mathrm{g} \mathrm{kg}^{-1} \mathrm{day}^{-1}$. These variations in Di may be attributed to the formation of soluble complexes in aqueous solutions of the weathered and altered overburden, and by basements caused by the metamorphic process [17].

\section{CONCLUSION}

The toxic element concentrations in some parts of Abuja were investigated. The Di derived from the measurements indicate slightly elevated $\mathrm{Cr}$ and $\mathrm{Pb}$ were reported at the Water Board location, with a magnitude of $10^{-7}$ and $10^{-4}$, respectively, for cancer mortality and morbidity. There was no potential health risk, as the values are far below the International Reference Dose by a magnitude of $10^{-1}$. The dose intake of heavy metals indicated that there may not be health risks associated with the heavy metals assessed in this present study, due to chemical toxicity in the water samples, but they may be mainly due to the radiotoxicity risk and its progeny. The long-term human exposure to harmful elements in water should be our concern, irrespective of how little the concentrations found were in water-based drinking collection areas in Abuja, Nigeria. The results of this study can be used as a baseline for future research in dose-related assessments of the area. It is recommended to determine the daughter elements of radionuclides in groundwater of other parts of Abuja, to know the long-term effect of these elements to human health in the study area.

\section{ACKNOWLEDGEMENTS}

The authors appreciate the support of Covenant University, Ota, Ogun State, Nigeria for the present study; as well as Universiti Teknologi Malaysia and Universiti Tun Hun Sun Malaysia, where the analysis was conducted through Assistant Professor Zaidi Embong. 


\section{REFERENCES}

[1] Karalliedde, L., \& Brooke, N., Toxicity of heavy metals and trace elements. Essentials of toxicology for health protection: A handbook for field professionals, Oxford University Press: Oxford, 2012.

[2] Pan, X.D., Tang, J., Chen, Q., Wu, P.G. \& Han, J.L., Evaluation of direct sampling method for trace elements analysis in Chinese rice wine by ICPeOES. European Food Research and Technology, 236(3), 2013. 531e535.

[3] Hao, X.Z., Zhou, D.M., Huang, D.Q., Cang, L., Zhang, H.L. \& Wang, H., Heavy metal transfer from soil to vegetable in southern Jiangsu Province, China. Pedosphere, 19(3), 2009. 305e311.

[4] Hernández-Martínez, R. \& Navarro-Blasco, I., Estimation of dietary intake and content of lead and cadmium in infant cereals marketed in Spain. Food Control, 26, 2012. $6 \mathrm{e} 14$.

[5] Kurttio, P., Komulainen, H., Leino, A., Salonen, L., Auvinen, A. \& Saha H., Bone as a Possible Target of Chemical Toxicity of Natural Uranium in Drinking Water. Environ Heal Perspectives, 113(1), pp. 68-72, 2005.

[6] Wei, B.G. \& Yang, L.S., A review of heavy metal contaminations in urban soils, urban road dusts and agricultural soils from China. Microchem Journal, 94, pp. 99$107,2010$.

[7] International Commission on Radiological Protection, Age-dependent doses to members of the public from intake of radionuclides: part 2 ingestion dose coefficients. Annals on the ICRP, publication 67, Pergamon Press: Oxford, 1993.

[8] International Atomic Energy Agency (IAEA), The Environmental Behaviour of Radium, (310), IAEA: Vienna, 1990.

[9] Omeje M., Wagiran, H., Ibrahim, N., Lee, S.K. \& Soheil, S., Comparison of ${ }^{238}$ U, ${ }^{232} \mathrm{Th}$, and ${ }^{40} \mathrm{~K}$ in different layers of subsurface structures in Dei-Dei and Kubwa, Abuja, Northcentral Nigeria. Radiation, Physics and Chemistry, 91, pp. 70-80, 2013.

[10] Agency for Toxic Substances and Disease Registry (ATSDR). ATSDR Toxicological Profile for Arsenic, TP-92/02, ATS DR, U.S. Department of Health and Human Services: Atlanta, GA, 1993.

[11] Pereira-Barbosa, J.T. et al., Bromine, chlorine, and iodine determination in soybean and its products by ICP-MS after digestion using microwave-induced combustion. Food Analytical Methods, 6(4), pp. 1065-1070, 2013.

[12] Tarvainen T. et al., Chemical composition of well water in Finland - main results of the "one thousand wells" project. Special Paper - Geological Survey of Finland, 31, pp. 57-76, 2001.

[13] United States Environmental Protection Agency (USEPA). Report No -13. Arsenic in drinking water Federal Guidance fact sheet, 2005. EPA. 402 R-99-001

[14] Environmental Protection Agency (EPA), Ground Water and Drinking Water. US Drinking Water Protection Division, Online. http://water.epa.gov/drink/(200.8).

[15] World Health Organization (WHO). Guidelines for drinking water quality. Health Criteria and Other Supporting Information, Addendum, 2(2), 1998.

[16] World Health Organization (WHO). WHO guidelines for drinking-water quality. $61^{\text {st }}$ meeting, Rome, 10-19 June. Joint FAO/WHO Expert Committee on Food Additives, 2004.

[17] IARC., Monographs on the evaluation of carcinogenic risks to humans, 1-58, IARC: Lyon, pp. 1972-1993, 1993. 
[18] United States Environmental Protection Agency (USEPA). Exposure factors handbook. Office of research and development, national centre for environmental assessment: Washington DC., 1997.

[19] Gbadebo, A.M., Natural radionuclides Distributions in granitic rocks and soils of abandoned quarry sites, Asian Journal of Applied Science 4: Abeokuta, Nigeria, pp. 176-185, 2011.

[20] United States Environmental Protection Agency (USEPA). Cancer risk coefficients for Environmental exposure to radionuclides, 1999. 